\title{
オレフィン系ハイブリッドポリマーの創出と展開
}

沉用樹脂であるポリオレフィンの高付加価值化を目指して, ポリオレフィンと極性ポリマーを化学結合でつ なげたオレフィン系ハイブリッドポリマーを創出した。本材料は従来の混合材料にはない種々の新しい性質 を有している。ハイブリッドポリマーの合成法から物性, および新しい用途展開について紹介した。

\section{斎藤純治*・柏 典夫**}

\section{Creation and Development of Novel Olefinic Hybrid Polymer}

Junji SAITO* and Norio KASHIWA**

Research Center, Mitsui Chemicals Inc.

E-mail: Junji.Saito@mitsui-chem.co.jp*

Abstract: Polyolefins are today considered to be indispensable materials. To broaden their applications even further, a lot of effort has been made to create new olefinic hybrid polymers, polyolefin/inorganic materials, and polyolefin/organic materials, etc. Recently, our research group successively produced polyolefin/polar polymer hybrid polymers by using controlled radical polymerization with PO macroinitiator method. In this paper, we will introduce and discuss the properties and applications of hybrid polymers by polyolefin macroinitiator method.

Keywords: Polyolefin/Polar Polymer/Hybrid Polymer/PO Macroinitiator/Controlled Radical Polymerization

\section{1.はじめに}

エチレン, プロピレンに代表されるオレフィンから製造 されるポリオレフィンは, 優れた機械強度・成型加工性・ 化学的安定性を有する材料として, 自動車部品, 産業資材, 生活資材などの幅広い分野で用いられている。ポリオレ フィンの中で高密度ポリエチレン, 低密度ポリエチレン, ポリプロピレンは 5 大汎用樹脂のうちの三つを占め, 世界 の熱可塑性樹脂の $2 / 3$ にあたる年間 1 億トン以上が生産 されている。また，今なおポリオレフィンに関する製造 （触媒, プロセス）技術, 成型加工技術などの分野の研究開 発が数多く行われている。その中で，ポリオレフィンと異 種の成分からなる複合材料は多くの関心が寄せられ，ポリ オレフィンとタルク, シリカ, クレイなどの無機材料, 炭 素繊維, カーボンナノチューブなどの有機材料からなる材 料の研究開発が知られている1) 4)。これらの複合材料は, いかに異種成分をポリオレフィン中に微分散化させ，それ によって新しい性質を発現させるかが開発の焦点となって いる。本稿では，ポリオレフィンと極性ポリマーを化学結
合でつないだ複合材料であるオレフィン系ハイブリッドポ リマーの合成法, 構造・物性の特徴および新材料としての 展開の可能性について述べる。

\section{2. オレフィン系ハイブリッドポリマーの合成法}

炭化水素化合物であるポリオレフィンは，他の基質と相 互作用する部分をむたないため, 物理的にポリオレフィン 之極性ポリマーを混合しただけでは，均一に微分散化させ ることが困難である。そこでポリオレフィンと極性ポリ マーが化学結合でつながったオレフィン系ハイブリッドポ リマーを設計した。オレフィン系ハイブリッドポリマーを 合成するためには，ポリオレフィン中に官能基を導入し， つづいて極性ポリマー部分を合成する方法が有効である。

官能基含有ポリオレフィンは, 遷移金属錯体触媒による オレフィンと極性モノマーの共重合，重合系への連鎖移動 剂添加, ポリオレフィン骨格に直接化学反応で官能基を導 入する方法などで合成することができる5) 8\}。

オレフィン系ハイブリッドポリマー合成法として，(1)
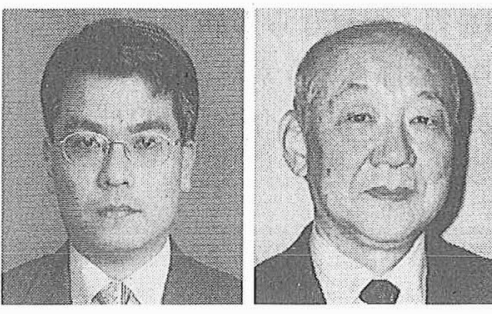

* (左)

三井化学(株)研究本部特別研究室（299-0265 袖ケ浦市長浦 580-32)。1990年大阪大学大学 院理学研究科博士前期課程修了. 専門は高分子化学, 触媒科学.

** (右)

同上・室長，シニアリサートフェロー，工学博士. 1966年 大阪大学工学部工学研究科修了. 専門は触媒科学, 高分子化学. 


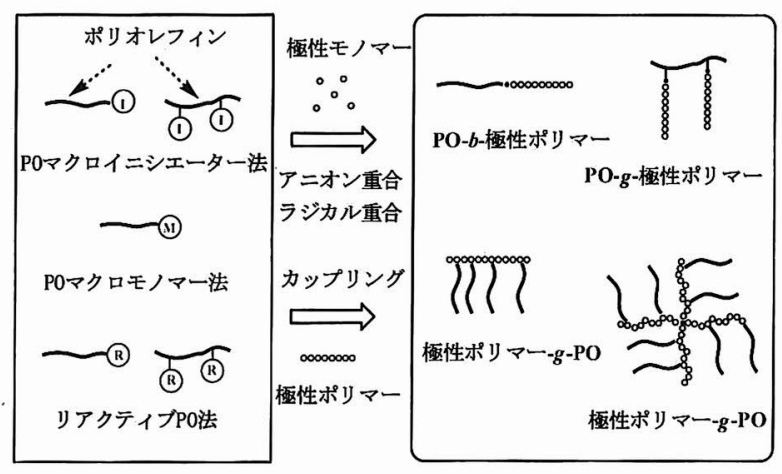

図 1 オレフィン系ハイブリッドポリマーの合成法

官能基含有ポリオレフィンの官能基を開始点として極性モ ノマーの制御ラジカル重合，またはアニオン重合を行う POマクロイニシエーター法, (2) 重合性の官能基を導入し たポリオレフィンと極性モノマーとの共重合を行う PO マ クロモノマー法, (3) 官能基含有ポリオレフィンと極性ポ リマーをカップリング反応で結合させるリアクティブ PO 法などが考えられる。原料の官能基含有ポリオレフィンの 構造・組成, および合成法の選択により, ブロック型, グ ラフト型, 星型の一次構造を有するオレフィン系八イブ リッドポリマーを合成することができる ${ }^{9) \sim 17)}$ (図 1)。

\section{PO マクロイニシエーター法による合成}

官能基含有ポリオレフィンとして, 水酸基含有ポリエチ レン, ポリプロピレンを用いる方法が有用である。エチレ ンまたはプロピレンと有機アルミニウムにより水酸基を保 護した水酸基含有オレフィンを遷移金属触媒（メタロセン 触媒）によって共重合した後, 加水分解することで片末端 のみに水酸基を導入したポリエチレン $(\mathrm{PE}-t-\mathrm{OH})$ ，ポリ マー鎖中に水酸基含有アルキル基がグラフトされたポリプ

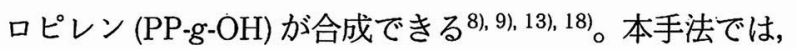
共重合条件（触媒，モノマー種，モノマー濃度など）の選 択によりポリオレフィン部分の組成，分子量，および水酸 基導入位置などの精密設計が可能である。つづいて生成し た PE-t-OH，PP-g-OH の水酸基を2-ブロモイソ酪酸ブロ ミドと反応させることで, リビングラジカル重合 ${ }^{19) ~ 21) の ~}$ 開始点となる官能基含有ポリエチレン (PE- $t$-Br), ポリプロ ピレン (PP-g-Br) が合成できる。このようにして合成した $\mathrm{PE}-t-\mathrm{Br}, \mathrm{PP}-\mathrm{g}-\mathrm{Br}$ をPO マクロイニシエーターとして用い る。極性モノマーのメチルメタクリレート (MMA)を $\mathrm{CuBr} / \mathrm{PMDETA}\left(N, N, N^{\prime}, N^{\prime \prime}, N^{\prime \prime}\right.$-ペンタメチルジェチレ ントリアミン）触媒存在下で重合することにより, PE- $b$ PMMA, PP-g-PMMA が生成する (図 2)。重合可能な極性 モノマーとして，アクリレート，メタクリレート，アクリ ロニトリル，アクリルアミド，スチレンなどが選択可能で あり，これらのモノマーを組成として含むハイブリッドポ

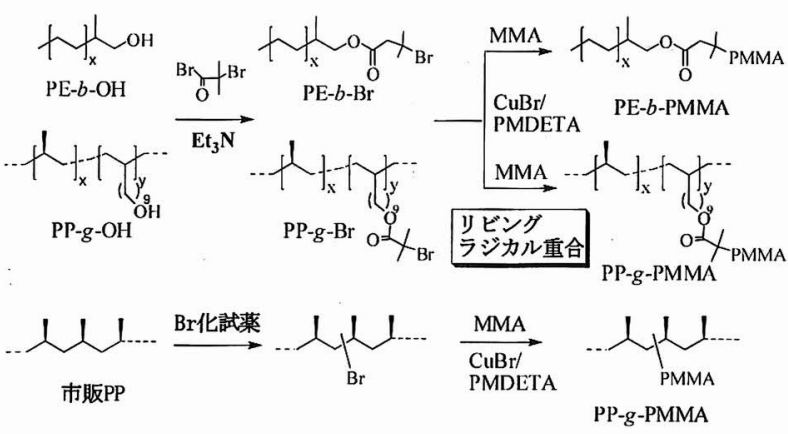

図2 PO マイクロイニシエーター法によるハイブリッドポ リマー合成

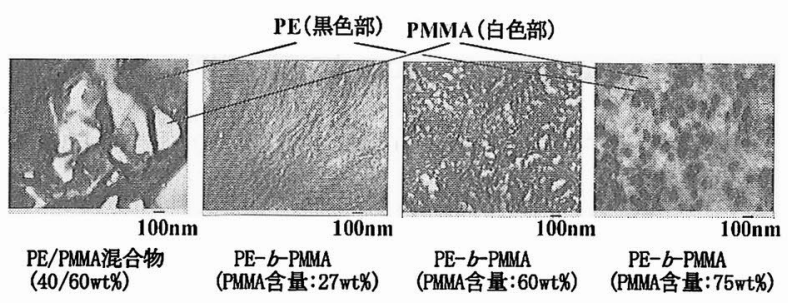

図 3 PE- $b$-PMMA の相分離構造（TEM 画像）

リマーが合成できる。本方法は, ポリオレフィン部分, 極 性ポリマー部分の双方の構造の精密制御が可能であるこ 之, 極性ポリマーのホモポリマーの副生量が非常に少ない ことから，分子設計どおりの合成が容易である。したがっ て, ハイブリッドポリマーの構造と物性の相関関係を調ベ るのに最適な方法である。一方，より簡便に合成できる PO マクロイニシエーターとして, 製品のポリプロピレン をNBS などの臭素化試薬で処理した臭素化ポリプロピレ ンを用いることもできる。本方法では, ポリオレフィン部 分の構造選択の幅は狭いものの, 製品ポリオレフィンを原 料として用いることができるためコスト面で有利な方法で ある(図 2)。

\section{4. オレフィン系ハイブリッドポリマーの特徴}

相溶性のないポリオレフィンと極性ポリマーを化学結合 でつないだオレフィン系八イブリッドポリマーは, 両成分 がナノメートルスケールで微分酸化した構造を示す。ポリ エチレンと PMMA の混合物と PE-b-PMMA の相構造の TEM 画像を図 3 に示す9)。

ポリエチレンと PMMA の混合物は, 明らかに両成分が 分離して混じり合わないが, PE-b-PMMA ではポリエチレ ン成分と PMMA 成分が 100 ナノメートル以下で微分散 化している。また, PMMA 成分比が低い場合はポリエチ レンマトリックス中に PMMA 成分が分散し, PMMA 成 分比が高くなると PMMA マトリックス中にポリエチレン 成分が分散する。この例から，オレフィン系ハイブリッド ポリマーの相構造は, ポリオレフィン成分と極性ポリマー 成分の量比によって変わることがわかる。 

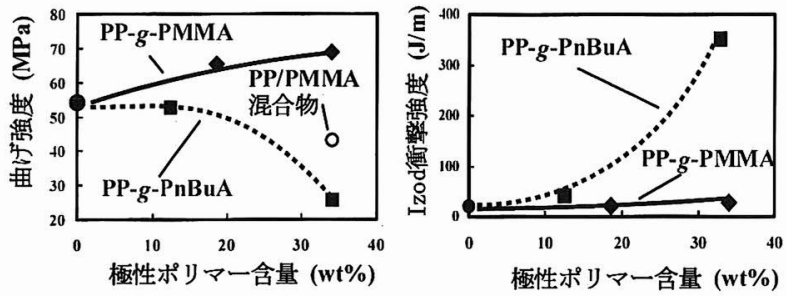

図 4 PP-g-PMMS, PP-g-PnBuA の機械物性
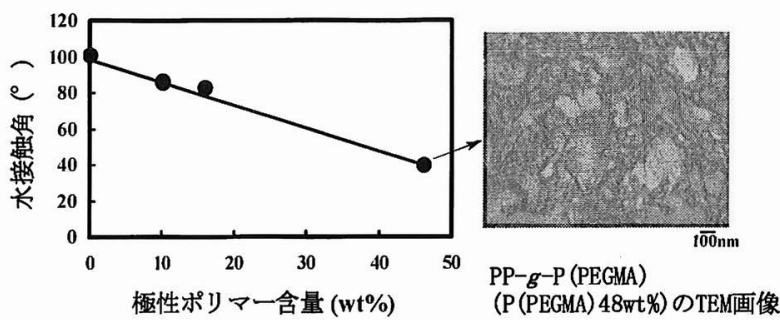

図 5 PP-g-P(PEGMA) シートの水接触角

オレフィン系ハイブリッドポリマーの機械物性変化を調 ベた結果を図 4 に示す18)。ポリプロピレンに極性ポリマー 成分として PMMA, PnBuA（ポリ-n-ブチルアクリレー ト）をグラフトさせた PP-g-PMMA, PP-g-PnBuA の極性 ポリマー含量と物性の関係をプロットした結果, 硬質成分 である PMMA 成分量を増加させていくと曲げ強度 (FS) がそれに伴って向上 $(54.3 \rightarrow 68.8 \mathrm{MPa})$ する。ポリプロピ レンと PMMA の単なる混合物では逆に FS は下がること から，ハイブリッド化が FS 向上につながっている。

一方, 軟質成分である $\mathrm{PnBuA}$ 成分量を $35 \mathrm{wt} \%$ まで増 加させていくと, FS は低下するあのの, Izod 衝撃強度が 大幅に向上する $(20.5 \rightarrow 353.7 \mathrm{~J} / \mathrm{m})$ 。これらの結果は, 極性 ポリマー成分がポリプロピレンのマトリックス中に微分散 した相構造に由来したあのと考えられる。オレフィン系八 イブリッドポリマーは，極性ポリマー成分を選択してポリ オレフィン部分とハイブリッド化することで，ポリオレ フィンの機械物性を向上させることが可能である。

また，ポリオレフィンに親水性を付与することす可能で ある。高親水性モノマーである PEGMA（ポリエチレング リコールメタクリレート) をポリプロピレンにグラフトさ せた PP-g-P(PEGMA) を合成し，そのシート成型物表面の 水接触角を測定すると $\mathrm{P}(\mathrm{PEGMA})$ 含量が増加するに従っ て值が小さくなり，親水性が付与されていることがわかる (図 5)。

P (PEGMA) 成分が $48 \mathrm{wt} \%$ ときの相構造を観察する と, ポリプロピレン成分と P(PEGMA) 成分が連続相を形 成しており，このような相構造が親水性向上につながるこ とが示唆される。

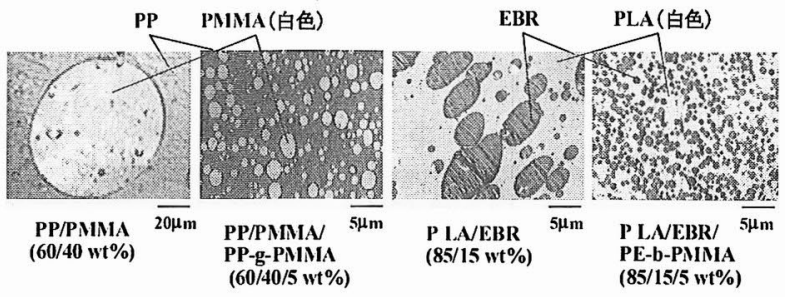

図 6 PP/PMMA アロイ, PLA/EBR アロイの相構造 (TEM 画像)

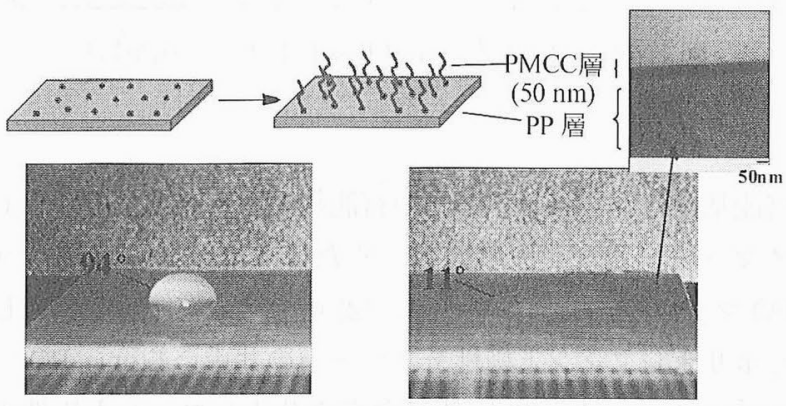

図 7 PP シート vs. 表面 PMCC 修飾 PP シート

\section{5. 新材料としての展開}

\section{1 相溶化剤}

オレフィン系ハイブリッドポリマーの有望な用途の一つ として, ポリオレフィンと極性ポリマーのアロイ用相溶化 剤が考えられる。ハイブリッドポリマーが，アロイ化時に 生成するポリオレフィン成分相之極性ポリマー成分相の界 面に存在することで, 両成分を微分散化させる効果が期待 できるからである。ポリプロピレンと PMMA の混合ポリ マー（重量比=60/40 wt\%）に相溶化剤として PMMA 含 量 $40 \mathrm{wt} \%$ の PP-g-PMMA を $5 \mathrm{wt} \%$ 添加すると, ポリプ ロピレンマトリックス中で PMMA 成分が微分散化し， そ の結果, 曲げ弾性率 (FM: $1801 \rightarrow 2200 \mathrm{MPa}$ ), 曲げ強度 (FS: 35.3 $\rightarrow 61.4 \mathrm{MPa}$ ) がともに向上する。また, ポリ乳酸 (PLA) と EBR（エチレン/ブテン共重合体）の混合物に対 し 5\%の PE- $b$-PMMA (PMMA 含量 $75 \mathrm{wt} \%$ ) を相溶化剂 として添加すると, ポリ乳酸マトリックス中の EBR 成分 が微分散化し, その結果 Izod 衝撃強度が大幅に向上 $(72 \rightarrow$ $378 \mathrm{~J} / \mathrm{m}$ ) する（図 6)。

このように，ポリオレフィン成分と極性ポリマー成分に 相溶化剤としてオレフィン系ハイブリッドポリマーを添加 することで, 物性の向上が可能である。今後, 用途に合わ せてポリオレフィン, 極性ポリマー, 相溶化剤としてのハ イブリッドポリマーを精密設計することにより, 新しいア ロイ材料の開発が期待できる。

\section{2 ポリオレフィン表面修飾}

ハイブリッドポリマー合成技術をポリオレフィンの表面 修飾に適用することで, 表面に極性ポリマー層を有するポ 
リオレフィンを合成することができる。PP マクロイニシ エーターである PP-g-Brをシート成型し，その表面で 4 級 アンモニウム塩を分子内に有するメタクリルコリンクロリ ド (MCC)のリビングラジカル重合を行うと， $50 \sim 60 \mathrm{~nm}$ のポリメタコリンクロリド (PMCC) 層を表面層に有する シートが合成できる。生成したシートは，重合前のシート 之比較して表面での水接触角が大幅に低下 $\left(94^{\circ} \rightarrow 11^{\circ}\right)$ し, 高い親水性を有している（図 7)。また，ハイブリッド化し たシートを空気中で 2 週間以上放置してあ水接触角の值 は変化せず, 従来の物理変性 (コロナ, プラズマ, UV 変性 など）したシートと異なり，親水性が長期持続する特徵を 有している。また, 本シートは抗菌性試験に扮いて大腸菌, 黄色ブドウ球菌が接種 24 時間後でほとんど死隇（非修飾 シート: 大腸菌 4,800 倍, 黄色ブドウ球菌 5.5 倍に繁殖)す る性質を有し，極性ポリマー成分である PMCC の抗菌性 がポリプロピレンシート上でそのまま発現する。このよう なポリオレフィン表面層でのハイブリッド化は，ポリオレ フィン製のシートだけではなく, フィルム, 緎維, 粒子な どの表面であ同㥞に可能である。本技術により，極性ポリ マーを選択することでポリオレフィンにさまざまな物性 （親水性，抗菌性，生体適合性，接着性，刺激応答性など） を有する表面層を制御して付与することが可能になり，ポ リオレフィンに新たな物性を付与する新材料開発あ期待で きる。

\section{6. おわりに}

ポリオレフィンと極性ポリマーからなるオレフィン系八 イブリッドポリマーの合成, 構造之物性の特徴, および新 材料としての展開の可能性について紹介した。今後オレ フィン系八イブリッドポリマーは, 従来のポリオレフィン に新しい性質を付与した高付加価値材料として発展してい くことが期待できる。

\section{文献}

1) M. Kawasumi, N. Hasegawa, M. Kato, A. Usuki, A. Okada: Macromolecules, 30, 6333 (1997)

2) M. Kato, H. Okamoto, N. Hasegawa, A. Tsukigase, A. Usuki: Polym. Eng. Sci., 43, 1312 (2003)

3) S. Kumar, H. Doshi, M. Srinivasaro, J. O. Park, D. A. Schiraldi: Polymer, 43, 1701 (2002)

4) K. Wiemann, W. Kaminsky, F. H. Gojny, K. Shulte: Macromol. Chem. Phys., 206, 1472 (2005)

5) R. Mülhaupt, T. Duschek, and B. Rieger: Makromol. Chem. Makromol. Symp., 48/49, 317 (1991)

6) T. C. Chung: Prog. Polym. Sci., 27, 39 (2002)

7) M. J. Yanjarappa, S. Sivaram: Prog. Polym. Sci., 27, 1347 (2002)

8) J. Imuta, N. Kashiwa, Y. Toda: J. Am. Chem. Soc., 124, 1176 (2002)

9) T. Matsugi, S. Kojoh, N. Kawahara, S. Matsuo, H. Kaneko, N. Kashiwa: J. Polym. Sci. A, 41, 3965 (2003)

10）斎藤純治，川原信夫，松尾真吾，金子英之，松木智昭，柏 典 夫：高分子論文集, 64, 897 (2007)

11) N. Kawahara, J. Saito, S. Matsuo, H. Kaneko, T. Matsugi, N. Kashiwa: Adv. Polym. Sci., in press

12) J-Y. Dong, Y. Hu: Coord. Chem. Rev., 250, 47 (2006)

13) N. Kashiwa, T. Matsugi, S. Kojoh, H. Kaneko, N. Kawahara, S. Matsuo, T. Nobori, J. Imuta: J. Polym. Sci. A., 41, 3657 (2003)

14) H. Kaneko, S. Kojoh, N. Kawahara, S. Matsuo, T. Matsugi, N. Kashiwa: J. Polym. Sci. A, 43, 5103 (2005)

15) N. Kawahara, S. Kojoh, S. Matsuo, H. Kaneko, T. Matsugi, N. Kashiwa: Polym. Bull., 57, 805 (2006)

16) S. Matsuo, T. Matsugi, J. Saito, N. Kawahara, H. Kaneko, N. Kashiwa: Stud. Surf. Sci. and Cat., 161, 1 (2006)

17) N. Kawahara, J. Saito, S. Matsuo, H. Kaneko, T. Matsugi, N. Kashiwa: Polym. Bull., 59, 177 (2007)

18) H. Kaneko, S. Matsuo, N. Kawahara, J. Saito, T. Matsugi, N. Kashiwa: Macromol. Symp., 260, 9 (2007)

19) K. Matyjaszewski, J. Xia: Chem. Rev., 101, 2921 (2001)

20) M. Kamigaito, T. Ando, M. Sawamoto: Chem. Rev., 101, 3689 (2001)

21) C. J. Hawker, A. W. Bosman, E. Harth: Chem. Rev., 101, 3661 (2001) 